\title{
Design, Synthesis, and Biological Evaluation of Prazosin Related Derivatives as Multipotent Compounds
}

Alessandra Antonello, ${ }^{\dagger}$ Patrizia Hrelia, ${ }^{\text {g }}$ Amedeo Leonardi, ${ }^{\sharp}$ Gabriella Marucci, ${ }^{\dagger}$ Michela Rosini, ${ }^{\dagger}$ Andrea Tarozzi, ${ }^{9}$ Vincenzo Tumiatti, ${ }^{\dagger}$ and Carlo Melchiorre ${ }^{* \dagger}$

Departments of Pharmaceutical Sciences and Pharmacology, Alma Mater Studiorum, University of Bologna, Via Belmeloro 6, 40126 Bologna, Italy, Research and Development Division, Recordati S.p.A., Via Civitali 1, 20148 Milano, Italy, and Department of Chemical Sciences, University of Camerino, Via S. Agostino 1, 62032 Camerino (MC), Italy

\section{Supporting Information}

Contents of SI: Contains experimental details for the synthesis and for the determination of the biological activity, spectra data and elemental analysis data (Appendix) for all new compounds.

\footnotetext{
${ }^{*}$ To whom correspondence should be addressed. Phone +39-051-2099706. Fax: +39-051-2099734. E-mail: carlo.melchiorre@unibo.it.

${ }^{\dagger}$ Department of Pharmaceutical Sciences, University of Bologna

Is Department of Pharmacology, University of Bologna

${ }^{\#}$ Recordati S.p.A.

\#niversity of Camerino
} 


\section{Experimental Section}

General procedure for the synthesis of $2-4$. A solution of $\mathbf{6}^{1}(0.17 \mathrm{~g}, 0.59 \mathrm{mmol})$ and 1.18 mmol of $7,8^{2}$ or $9^{3}$ in dry DMF $(5 \mathrm{~mL})$ was cooled $\left(0^{\circ} \mathrm{C}\right)$ and treated, under $\mathrm{N}_{2}$, with EDCIHCl $(0.14 \mathrm{~g}, 0.71 \mathrm{mmol})$. Resulting mixture was stirred $15 \mathrm{~min}$ at $0{ }^{\circ} \mathrm{C}$ and $2 \mathrm{~h}$ at room temperature in the dark. Removal of the solvent under vacuum at room temperature gave a residue that was dissolved in aqueous $\mathrm{NaHCO}_{3}$ saturated solution and extracted with chloroform. Evaporation of the dried organic extracts afforded a residue that was purified by flash chromatography.

Compound 2: eluting solvent, $\mathrm{CHCl}_{3}-\mathrm{MeOH}(9.7: 0.3)$; $43 \%$ yield; mp 191-193 ${ }^{\circ} \mathrm{C} ;{ }^{1} \mathrm{H}$ NMR $\left(\mathrm{CDCl}_{3}\right) \delta$ 1.43-1.82 (m, 6), 1.88-2.02 (m, 1), 2.36-2.56 (m + t, 3), 3.08-3.27 (m, 2), 3.45-3.68 (m, 3), 3.70-3.78 (m, 2), 3.80-3.93 (m, 4), $3.96(\mathrm{~s}, 3), 4.00(\mathrm{~s}, 3), 5.20\left(\right.$ br s, 2, exchangeable with $\left.\mathrm{D}_{2} \mathrm{O}\right)$, $6.82(\mathrm{~s}, 1), 6.94$ (s, 1). Anal. $\left(\mathrm{C}_{22} \mathrm{H}_{31} \mathrm{~N}_{5} \mathrm{O}_{3} \mathrm{~S}_{2}\right) \mathrm{C}, \mathrm{H}, \mathrm{N}$.

Compound 3: eluting solvent, $\mathrm{CHCl}_{3}-\mathrm{MeOH}(9.4: 0.6)$; $15 \%$ yield; mp $160-162{ }^{\circ} \mathrm{C} ;{ }^{1} \mathrm{H}$ NMR $\left(\mathrm{CDCl}_{3}\right) \delta$ 1.98-2.11 (m, 1), 2.57-2.70 (m, 1), 2.72-2.98 (m, 2), 3.14-3.30 (m, 2), 3.49-3.66 (m, 2), 3.66-3.84 (m, 2), 3.84-3.95 (m, 4), $3.96(\mathrm{~s}, 3), 4.00(\mathrm{~s}, 3), 4.15-4.27(\mathrm{~m}, 1), 5.20$ (br s, 2, exchangeable with $\left.\mathrm{D}_{2} \mathrm{O}\right), 6.82(\mathrm{~s}, 1), 6.95(\mathrm{~s}, 1)$. MS $\left(\mathrm{ESI}^{+}\right) \mathrm{m} / z 436(\mathrm{M}+\mathrm{H})^{+}$. Anal. $\left(\mathrm{C}_{19} \mathrm{H}_{25} \mathrm{~N}_{5} \mathrm{O}_{3} \mathrm{~S}_{2}\right)$ $\mathrm{C}, \mathrm{H}, \mathrm{N}$.

Compound 4: eluting solvent, $\mathrm{CHCl}_{3}-\mathrm{MeOH}$ (9.8:0.2); $41 \%$ yield; mp 142-145 ${ }^{\circ} \mathrm{C}$; ${ }^{1} \mathrm{H}$ NMR $\left(\mathrm{CDCl}_{3}\right)$ 2.18-2.36 (m, 1), 2.93-3.09 (m, 1), 3.22-3.36 (m, 1), 3.37-3.49 (m, 1), 3.50-3.94 (m, 8), $3.96(\mathrm{~s}, 3), 4.00(\mathrm{~s}, 3), 4.36-4.45(\mathrm{~m}, 1), 5.19$ (br s, 2, exchangeable with $\left.\mathrm{D}_{2} \mathrm{O}\right), 6.81(\mathrm{~s}, 1), 6.94(\mathrm{~s}$, 1). MS $\left(\mathrm{ESI}^{+}\right) m / z 422(\mathrm{M}+\mathrm{H})^{+}$. Anal. $\left(\mathrm{C}_{18} \mathrm{H}_{23} \mathrm{~N}_{5} \mathrm{O}_{3} \mathrm{~S}_{2}\right) \mathrm{C}, \mathrm{H}, \mathrm{N}$.

Compound 5 was obtained by adding a solution of $6(0.10 \mathrm{~g}, 0.35 \mathrm{mmol})$ in EtOH $(5 \mathrm{~mL})$ to a suspension of $\mathbf{1 0}$. Resulting mixture was heated at $70{ }^{\circ} \mathrm{C}$ for a week; the solvent was then removed to afford a residue that was purified by flash chromatography. Eluting with $\mathrm{CH}_{2} \mathrm{Cl}_{2}-\mathrm{EtOH}(9.6: 0.4)$ provided 5 as a red brilliant solid: $13 \%$ yield; mp 138-140 ${ }^{\circ} \mathrm{C} ;{ }^{1} \mathrm{H}$ NMR $\left(\mathrm{CDCl}_{3}\right) \delta 3.62-3.68(\mathrm{~m}, 4)$, $3.95(\mathrm{~s}, 3), 4.00(\mathrm{~s}, 3), 4.01-4.07(\mathrm{~m}, 4), 5.23$ (br s, 2, exchangeable with $\left.\mathrm{D}_{2} \mathrm{O}\right), 6.07(\mathrm{~s}, 1), 6.83(\mathrm{~s}$, 
1), $6.95(\mathrm{~s}, 1), 7.62-7.78(\mathrm{~m}, 2), 8.01-8.10(\mathrm{~m}, 2) . \mathrm{MS}\left(\mathrm{ESI}^{+}\right) \mathrm{m} / z 446(\mathrm{M}+\mathrm{H})^{+}$. Anal. $\left(\mathrm{C}_{24} \mathrm{H}_{23} \mathrm{~N}_{5} \mathrm{O}_{4}\right)$

C, H, N.

Cell cultures. Lymph node carcinoma of the prostate ( $\mathrm{LNCaP})$ cells were routinely grown at 37 ${ }^{\circ} \mathrm{C}$ in a humidified incubator with $5 \% \mathrm{CO}_{2}$ in RPMI 1640 medium supplemented with $10 \%$ fetal calf serum (FCS), $2 \mathrm{mM}$ glutamine, $50 \mathrm{U} / \mathrm{mL}$ penicillin and $50 \mu \mathrm{g} / \mathrm{mL}$ streptomycin.

Determination of antiproliferative activity. The antiproliferative activity was evaluated with CellTiter $96^{\circledR}$ Aqueous Non-Radioactive Cell Proliferation assay (Promega Corp., Madison, Winsconsin, USA) according to the manufacturer's instructions. Briefly, LNCaP cells were seeded in 96-well microtiter plates at a density of $1.5 \times 10^{4}$ cells $/ \mathrm{cm}^{2}$. After $24 \mathrm{~h}$ of incubation at $37{ }^{\circ} \mathrm{C}$ in $5 \% \mathrm{CO}_{2}$, the growth medium was removed and media containing compounds $(1-100 \mu \mathrm{M})$ were added to the cells. After $72 \mathrm{~h}$ of incubation, $40 \mu \mathrm{L}$ of solution with MTS (3-(4,5-dimethylthiazol-2yl)-5-(3-carboxymethoxyphenyl)-2-(4-sulfophenyl)-2H-tetrazolium, inner salt) and PMS (phenazine methosulfate, electron coupling reagent) was added to each well of the plate. After further $4 \mathrm{~h}$ of incubation, the amount of formazan was measured $(405 \mathrm{~nm})$ with a spectrophotometer (Spectra model Classic, TECAN ${ }^{\circledR}$ ). The cell proliferation was expressed as percentage of control cells and calculated by the formula $F_{t} / F_{n t} \times 100$, where $F_{t}=$ absorbance of treated cells and $F_{n t}=$ absorbance of not-treated cells.

Determination of intracellular antioxidant activity. The antioxidant activity of compounds was evaluated by measuring the formation of intracellular reactive oxygen species (ROS) evoked by exposure of LNCaP cells to tert-butyl hydroperoxide $(t-\mathrm{BuOOH})$, a compound used to induce oxidative stress. Formation of intracellular ROS was determined using a fluorescent probe 2',7'dichlorodihydrofluorescein diacetate (DCFH-DA), as described by Rosenkranz and co-workers. ${ }^{4}$ Briefly, the LNCaP cells were seeded in $100 \mathrm{~mm}$ culture dishs, at a density of $6 \times 10^{4}$ cells $/ \mathrm{cm}^{2}$. After $24 \mathrm{~h}$ of incubation at $37{ }^{\circ} \mathrm{C}$ in $5 \% \mathrm{CO}_{2}$, the growth medium was removed and media containing compounds were added to the cells. After $24 \mathrm{~h}$ of incubation, LNCaP cells were collected and suspended at a concentration of $1 \times 10^{6}$ cells $/ \mathrm{mL}$ in $2 \mathrm{~mL}$ of phosphate buffered saline 
(PBS) and then incubated for 30 min with $10 \mu \mathrm{M}$ of DCFH-DA in PBS at $37^{\circ} \mathrm{C}$ in $5 \% \mathrm{CO}_{2}$. After removal of DCFH-DA, the LNCaP cells were washed with PBS and incubated with $0.1 \mathrm{mM}$ of $t$ $\mathrm{BuOOH}$ in PBS for $30 \mathrm{~min}$ at $37^{\circ} \mathrm{C}$. At the end of incubation, the fluorescence of LNCaP cells was measured $\left(\lambda_{\text {excitation }}=485 \mathrm{~nm}, \lambda_{\text {emission }}=535 \mathrm{~nm}\right)$ with a spectrofluometer $\left(\right.$ Wallac Victor ${ }^{\circledR}$ Multilabel Counter, Perkin Elmer Inc., Boston, MA). Intracellular antioxidant activity was expressed as percentage inhibition of intracellular ROS evoked by exposure to $t-\mathrm{BuOOH}$ and calculated by the formula $\left\{100-\left[\left(\mathrm{F}_{\mathrm{tc}}-\mathrm{F}_{\mathrm{nt}} / \mathrm{F}_{\mathrm{t}}-\mathrm{F}_{\mathrm{nt}}\right) \times 100\right]\right\}$, where $\mathrm{F}_{\mathrm{tc}}=$ fluorescence of compound- and $t$ $\mathrm{BuOOH}$-treated neurones, $\mathrm{F}_{\mathrm{t}}=$ fluorescence of $t-\mathrm{BuOOH}$-treated neurones and $\mathrm{F}_{\mathrm{nt}}=$ fluorescence of not-treated neurones.

Functional Antagonism in Isolated Tissues. Male Wistar rats (275-300 g) were killed by cervical dislocation, and the organs required were isolated, freed from adhering connective tissue, and set up rapidly under a suitable resting tension in $20 \mathrm{~mL}$ organ baths containing physiological salt solution kept at $37{ }^{\circ} \mathrm{C}$ and aerated with $5 \% \mathrm{CO}_{2}: 95 \% \mathrm{O}_{2}$ at $\mathrm{pH}$ 7.4. Concentration-response curves were constructed by cumulative addition of agonist. The concentration of agonist in the organ bath was increased approximately 3-fold at each step, with each addition being made only after the response to the previous addition had attained a maximal level and remained steady. Contractions were recorded by means of a force displacement transducer connected to the MacLab system PowerLab/800. In addition, parallel experiments in which tissues did not receive any antagonist were run in order to check any variation in sensitivity.

Rat Vas Deferens Prostatic Portion. This tissue was used to assess $\alpha_{1 \mathrm{~A}}$-adrenergic antagonism. ${ }^{5}$ Prostatic portions of $2 \mathrm{~cm}$ length were mounted under $0.5 \mathrm{~g}$ tension in Tyrode solution of the following composition (mM): $\mathrm{NaCl}, 130.0 ; \mathrm{KCl}, 2.0 ; \mathrm{CaCl}_{2}, 1.8 ; \mathrm{MgCl}_{2}, 0.89 ; \mathrm{NaHCO}_{3}, 25.0$; $\mathrm{NaH}_{2} \mathrm{PO}_{4}, 0.42$; glucose, 5.6. Cocaine hydrochloride $(0.1 \mu \mathrm{M})$ was added to the Tyrode to prevent the neuronal uptake of (-)-noradrenaline. The preparations were equilibrated for $60 \mathrm{~min}$ with washing every $15 \mathrm{~min}$. After the equilibration period, tissues were primed two times by addition of $10 \mu \mathrm{M}(-)$-noradrenaline. After another washing and equilibration period of $60 \mathrm{~min}$, a (-)- 
noradrenaline concentration-response curve was constructed (basal response). The antagonist was allowed to equilibrate with the tissue for $30 \mathrm{~min}$, then a new concentration-response curve to the agonist was obtained. (-)-Noradrenaline solutions contained $0.05 \% \mathrm{Na}_{2} \mathrm{~S}_{2} \mathrm{O}_{5}$ to prevent oxidation.

Rat Spleen. This tissue was used to assess $\alpha_{1 \mathrm{~B}}$-adrenergic antagonism. ${ }^{6}$ The spleen was removed and bisected longitudinally into two strips which were suspended in tissue baths containing Krebs solution of the following composition (mM): $\mathrm{NaCl}, 120.0 ; \mathrm{KCl}, 4.7 ; \mathrm{CaCl}_{2}, 2.5 ; \mathrm{MgSO}_{4}, 1.5$; $\mathrm{NaHCO}_{3}, 20.0 ; \mathrm{KH}_{2} \mathrm{PO}_{4}$, 1.2; glucose, 11.0; $\mathrm{K}_{2}$ EDTA, 0.01. ( \pm )-Propranolol hydrochloride (4.0 $\mu \mathrm{M})$ was added to block $\beta$-adrenoreceptors. The spleen strips were placed under $1 \mathrm{~g}$ resting tension and equilibrated for $2 \mathrm{~h}$. The cumulative concentration-response curves to (-)-phenylephrine were measured isometrically and obtained at $30 \mathrm{~min}$ intervals, the first one being discarded and the second one was taken as control. The antagonist was allowed to equilibrate with the tissue for 30 min, then a new concentration-response curve to the agonist was constructed.

Rat Aorta. This tissue was used to assess $\alpha_{1 \mathrm{D}}$-adrenergic antagonism. ${ }^{7}$ Thoracic aorta was cleaned from extraneous connective tissue and placed in Krebs solution of the following composition (mM): $\mathrm{NaCl}, 118.4 ; \mathrm{KCl}, 4.7 ; \mathrm{CaCl}_{2}, 1.9 ; \mathrm{MgSO}_{4} 1.2 ; \mathrm{NaHCO}_{3}, 25.0 ; \mathrm{NaH}_{2} \mathrm{PO}_{4}, 1.2$; glucose, 11.7. Cocaine hydrochloride $(0.1 \mu \mathrm{M})$ and $( \pm)$-propranolol hydrochloride $(4.0 \mu \mathrm{M})$ were added to prevent the neuronal uptake of (-)-noradrenaline and to block $\beta$-ARs, respectively. Two helicoidal strips (15 mm x $3 \mathrm{~mm}$ ) were cut from each aorta beginning from the end most proximal to the heart. The endothelium was removed by rubbing with filter paper: the absence of acetylcholine (100 $\mu \mathrm{M})$-induced relaxation to preparations contracted with (-)-noradrenaline (1 $\mu \mathrm{M})$ was taken as an indicator that vessel was denuded successfully. Vascular strips were then tied with surgical thread and suspended in a jacketed tissue bath containing Tyrode solution. Strips were secured at one end to plexiglas hooks and connected to transducer for monitoring changes in isometric contraction. After at least $2 \mathrm{~h}$ equilibration period under an optimal tension of $2 \mathrm{~g}$, cumulative (-)-noradrenaline concentration-response curves were recorded at $1 \mathrm{~h}$ intervals, the first two being discarded and the third one taken as control. The antagonist was allowed to equilibrate 
with the tissue for $30 \mathrm{~min}$ before the generation of the fourth cumulative concentration-response curve to (-)-noradrenaline. (-)-Noradrenaline solutions contained $0.05 \% \mathrm{~K}_{2}$ EDTA and $0.9 \% \mathrm{NaCl}$ to prevent oxidation.

Radioligand Binding Assays. Binding to cloned human $\alpha_{1}$-AR subtypes was performed in membranes from $\mathrm{CHO}$ (chinese hamster ovary) cells transfected by electroporation with DNA expressing the gene encoding each $\alpha_{1}$-AR subtype. Cloning and stable expression of the human $\alpha_{1^{-}}$ AR gene was performed as previously described. ${ }^{9} \mathrm{CHO}$ cell membranes (30 $\mu \mathrm{g}$ proteins) were incubated in $50 \mathrm{mM}$ Tris- $\mathrm{HCl}, \mathrm{pH} 7.4$, with $0.1-0.4 \mathrm{nM}\left[{ }^{3} \mathrm{H}\right]$ prazosin, in a final volume of $1.02 \mathrm{~mL}$ for $30 \mathrm{~min}$ at $25^{\circ} \mathrm{C}$, in absence or presence of competing drugs $(1 \mathrm{pM}-10 \mu \mathrm{M})$. Non-specific binding was determined in the presence of $10 \mu \mathrm{M}$ phentolamine. The incubation was stopped by addition of ice-cold Tris- $\mathrm{HCl}$ buffer and rapid filtration through $0.2 \%$ polyethyleneimine pretreated Whatman GF/B or Schleicher \& Schuell GF52 filters.

Data Analysis. In functional studies responses were expressed as percentage of the maximal contraction observed in the agonist concentration-response curve taken as a control. Pharmacological computer programs analyzed the agonist concentration-response curves. $\mathrm{p} K_{\mathrm{B}}$ values of compounds 1-5 were calculated according to van Rossum. ${ }^{11}$

Binding data were analyzed using the non-linear curve-fitting program Allfit. ${ }^{12}$ Scatchard plots were linear in all preparations. All pseudo-Hill coefficients $(\mathrm{nH})$ were not significantly different from unity $(\mathrm{p}>0.05)$. Equilibrium inhibition constants $\left(K_{\mathrm{i}}\right)$ were derived from the Cheng-Prusoff equation, ${ }^{13} K_{\mathrm{i}}=\mathrm{IC}_{50} /\left(1+L / K_{\mathrm{d}}\right)$, where $L$ and $K_{\mathrm{d}}$ are the concentration and the equilibrium dissociation constant of the radioligand. $\mathrm{p} K_{\mathrm{i}}$ values are the mean $\pm \mathrm{SE}$ of 2-3 separate experiments performed in triplicate.

\section{References}

(1) Althuis, T. H.; Hess, H. J. Synthesis and identification of the major metabolites of prazosin formed in dog and rat. J. Med. Chem. 1977, 20, 146-149. 
(2) Lawton, R. G.; Chen, Y. S. An efficient synthetic route to 2-(1,2-dithiolan-3-yl)acetic acid. Trisnorlipoic and amide derivatives. Tetrahedron Lett. 1997, 38, 5785-5788.

(3) Claeson, G. 1,2-Dithiolane-3-carboxylic acid. Acta Chem. Scand. 1955, 9, 178-180.

(4) Rosenkranz, A. R.; Schmaldienst, S.; Stuhlmeier, K. M.; Chen, W.; Knapp, W.; Zlabinger, G. J. A microplate assay for the detection of oxidative products using 2',7'dichlorofluorescin-diacetate. J. Immunol. Methods 1992, 156, 39-45.

(5) Eltze, M.; Boer, R.; Sanders, K. H.; Kolassa, N. Vasodilatation elicited by 5-HT1A receptor agonists in constant-pressure-perfused rat kidney is mediated by blockade of $\alpha_{1 A^{-}}$ adrenoceptors. Eur. J. Pharmacol. 1991, 202, 33-44.

(6) Buckner, S. A.; Oheim, K. W.; Morse, P. A.; Knepper, S. M.; Hancock, A. A. $\alpha_{1^{-}}$ Adrenoceptor-induced contractility in rat aorta is mediated by the alpha 1D subtype. Eur. $J$. Pharmacol. 1996, 297, 241-248.

(7) Ko, F. N.; Guh, J. H.; Yu, S. M.; Hou, Y. S.; Wu, Y. C.; Teng, C. M. (-)-Discretamine, a selective $\alpha_{1 \mathrm{D}}$-adrenoceptor antagonist, isolated from Fissistigma glaucescens. $\mathrm{Br}$. $J$. Pharmacol. 1994, 112, 1174-1180.

(8) Ellman, G. L.; Courtney, K. D.; Andres, V.; Featherstone, R. M. A new rapid colorimetric determination of acetylcholinesterase activity. Biochem. Pharmacol. 1961, 7, 88-95.

(9) Testa, R.; Taddei, C.; Poggesi, E.; Destefani, C.; Cotecchia, S.; Hieble, J. P.; Sulpizio, A. C.; Naselsky, D.; Bergsma, D.; Ellis, S.; Swift, A.; Ganguly, S.; Ruffolo, R. R., Jr.; Leonardi, A. Rec 15/2739 (SB 216469): a novel prostate selective $\alpha_{1}$-adrenoceptor antagonist. Pharmacol. Commun. 1995, 6, 79-86.

(10) Dewar, M. J. S.; Zoebisch, E. G.; Healy, E. F.; Stewart, J. J. P. AM1: a new general purpose quantum mechanical molecular model. J. Am. Chem. Soc. 1985, 107, 3902-3909.

(11) Van Rossum, J. M. Cumulative dose-response curves. II. Technique for the making of dose-response curves in isolated organs and the evaluation of drug parameters. Arch. Int. Pharmacodyn. Ther. 1963, 143, 299-330. 
(12) DeLean, A.; Munson, P. J.; Rodbard, D. Simultaneous analysis of families of sigmoidal curves: application to bioassay, radioligand assay, and physiological dose-response curves. Am. J. Physiol. 1978, 235, E97-102.

(13) Cheng, Y. C.; Prusoff, W. H. Relationship between the inhibition constant $\left(K_{\mathrm{i}}\right)$ and the concentration of inhibitor which causes $50 \%$ inhibition $\left(\mathrm{I}_{50}\right)$ of an enzymatic reaction. Biochem. Pharmacol. 1973, 22, 3099-3108. 


\section{Appendix}

Elemental Analysis of Compounds 2-5

\begin{tabular}{llllllll}
\hline No. & Formula & \multicolumn{3}{c}{ Calcd., \% } & \multicolumn{3}{c}{ Found, \% } \\
\cline { 3 - 5 } \cline { 5 - 7 } & & $\mathrm{C}$ & $\mathrm{H}$ & $\mathrm{N}$ & $\mathrm{C}$ & $\mathrm{H}$ & $\mathrm{N}$ \\
\hline $\mathbf{2}$ & $\mathrm{C}_{22} \mathrm{H}_{31} \mathrm{~N}_{5} \mathrm{O}_{3} \mathrm{~S}_{2}$ & 55.32 & 6.54 & 14.66 & 55.63 & 6.21 & 14.52 \\
$\mathbf{3}$ & $\mathrm{C}_{19} \mathrm{H}_{25} \mathrm{~N}_{5} \mathrm{O}_{3} \mathrm{~S}_{2}$ & 52.39 & 5.79 & 16.08 & 52.10 & 5.89 & 16.31 \\
$\mathbf{4}$ & $\mathrm{C}_{18} \mathrm{H}_{23} \mathrm{~N}_{5} \mathrm{O}_{3} \mathrm{~S}_{2}$ & 51.29 & 5.50 & 16.61 & 51.12 & 5.75 & 16.81 \\
$\mathbf{5}$ & $\mathrm{C}_{24} \mathrm{H}_{23} \mathrm{~N}_{5} \mathrm{O}_{4}$ & 64.71 & 5.20 & 15.72 & 64.36 & 5.41 & 15.60 \\
\hline
\end{tabular}

